\title{
EDWARD FRANCISZEK CYRSON (1940-2018)
}

Edward Franciszek Cyrson urodził się 29 lipca 1940 r. w Tczewie. Studia wyższe na Wydziale Prawa Uniwersytetu im. Adama Mickiewicza w Poznaniu ukończył w 1964 r., uzyskując tytuł magistra prawa. Jednocześnie był słuchaczem sekcji ekonomicznej przy Wydziale Prawa. Po ukończeniu studiów prawniczych podjął pracę w Katedrze Ekonomii Politycznej Wydziału Prawa, po czym ukończył studia uzupełniające na Wydziale Ekonomii Politycznej Uniwersytetu Warszawskiego, uzyskując w 1966 r. tytuł magistra nauk ekonomicznych, co zaowocowało jego awansem na stanowisko starszego asystenta w Katedrze Ekonomii Politycznej Wydziału Prawa.

W roku akademickim 1967/1968 Edward Cyrson odbył studia ekonomiczne w Stanach Zjednoczonych, gromadząc jednocześnie materiały do swojej pracy doktorskiej zatytułowanej Koncentracja produkcji i kapitału a rozwój nowych technologii we wspótczesnym przemyśle przetwórczym USA. Obrona tej pracy odbyła się 12 lipca 1971 r. na Wydziale Handlu Zagranicznego w Szkole Głównej Planowania i Statystyki w Warszawie. Rada Wydziału przyznała Mu jednogłośnie tytuł doktora nauk ekonomicznych. Na Uniwersytecie został awansowany na stanowisko adiunkta.

W 1982 r. uzyskał tytuł doktora habilitowanego na Wydziale Handlu Zagranicznego w Szkole Głównej Planowania i Statystyki w Warszawie na podstawie rozprawy habilitacyjnej Korporacje wielonarodowe. Prawidtowości ekspansji zagranicznej oraz całego dorobku naukowego. Od $1983 \mathrm{r}$. był zatrudniony jako docent, a w 1993 r. został awansowany na stanowisko profesora nadzwyczajnego UAM.

W latach 1981-1982 dr Edwad Cyrson przebywał jako Visiting Professor of Marketing w California State University, School of Business Administration and Economics. Następnie po uzyskaniu stopnia naukowego doktora habilitowanego, w latach 1985-1987, jako Visiting Professor of Marketing w Lamar University, College of Business, Teksas. Nawiązał w ten sposób współpracę naukowo-badawczą oraz dydaktyczną z uczelniami amerykańskimi, co w późniejszym okresie zaowocowało wyjazdami szkoleniowymi i regularnymi studiami (także dającymi status absolwenta Harvard University) pracowników Katedry Nauk Ekonomicznych. Profesor Cyrson ukończył w 1992 r. International Senior Management Program w Harvard University Graduate School of Business Administration.

Profesor Edward Cyrson w latach 1982-1986 oraz 1991-1995 był kierownikiem Katedry Nauk Ekonomicznych na WPiA UAM. Był też założycielem i kierownikiem Studium Zarządzania i Marketingu (1991-2009), a od roku 2003 do 2010 kierownikiem Zakładu Zarządzania i Marketingu w ramach Katedry Nauk Ekonomicznych. W latach 1978-1985 był dyrektorem Letniej Szkoły Biznesu i Ekonomii dla Obcokrajowców na UAM. Był również założycielem, prezydentem i wykładowcą (1988-1994) Poznańskiej Szkoły Menedżerów.

Zainteresowania naukowe Profesora Edwarda Cyrsona koncentrowały się na zagadnieniach mikroekonomii, zarządzaniu i marketingu, strategiach konkurencji, rewolucji informacyjnej i nowych modelach biznesu, a także determinantach rozwoju małego i średniego biznesu. W tych obszarach badawczych mieszczą się także Jego publikacje (w tym podręczniki akademickie), prezentacje na konferencjach naukowych oraz zajęcia dydaktyczne. Jako dydaktyk cieszył się niezwykłym uznaniem i szacunkiem zarówno wśród studentów, jak i innych pracowników dydaktycznych, również zagranicznych (często był zapraszany do wygłaszania wykładów na amerykańskich uczelniach), znany był też m.in. z wprowadzania nowych technik nauczania w dziedzinie marketingu i zarządzania - w tym w szczególności action learning i case studies.

Żegnając Profesora Edwarda Cyrsona w imieniu własnym oraz obecnych i byłych pracowników Katedry Nauk Ekonomicznych, pragnę podkreślić Jego wkład w przygotowanie merytorycznego programu studiów i pokonanie licznych barier administracyjnych, dzięki czemu w $1991 \mathrm{r}$. pierwszy rocznik studentów Zarządzania i Marketingu mógł rozpocząć studia. Wyrażamy głęboka wdzięczność Profesorowi za Jego dzieło, które umożliwiło rozwój Katedry i w znaczącym stopniu zmieniło jej sytuację i status.

Osoby zatrudnione w Katedrze w latach dziewięćdziesiątych dokonały olbrzymiego wysiłku, aby przygotować się do prowadzenia zajęć dydaktycznych z przedmiotów, których nigdy wcześniej 
nie wykładały. Znaczacy udział w procesie nabywania i doskonalenia wiedzy merytorycznej oraz umiejętności dydaktycznych miał Profesor Cyrson. Dzięki swoim kontaktom międzynarodowym i usilnym staraniom umożliwił większości wykładowców (właściwie wszystkim chętnym) dodatkowe studia bądź pobyty studyjne w liczących się ośrodkach akademickich, kształcących w dziedzinie biznesu i zarządzania. Wykładowcy studiowali na uczelniach amerykańskich, takich jak Harvard Business School (Boston), Wharton School of Business (Filadelfia), Stanford University (San Francisco), Kellogg School of Business (Chicago), a także na uniwersytetach europejskich, takich jak: Louvain-la-Neuve czy Rennes. Poszerzanie i pogłębianie wiedzy w procesie badawczym przyczyniły się także do poprawy jakości dydaktyki - badania naukowe i dydaktyka bowiem stanowią nierozłączną całość pracy nauczyciela akademickiego.

Profesor Edward Cyrson był nie tylko uczonym o wielkim autorytecie i zasłużonym organizatorem studiów na Uniwersytecie im. Adama Mickiewicza, ale także człowiekiem wielkiej kultury. Odejście Profesora Edwarda Cyrsona jest wielką stratą dla Uniwersytetu oraz dla współpracowników i przyjaciół z Katedry Nauk Ekonomicznych.

Elżbieta Jantoń-Drozdowska 